\title{
Wearable PPG Sensor Matrix for Cardiovascular
} Assessment

\author{
Viktorija Mecnika ${ }^{1}$,Edgars Kviesis-Kipge ${ }^{2}$, Ivars Krievinušs ${ }^{3}$, Zbignevs Marcnikevics ${ }^{4}$, Anne Schwarz ${ }^{5}$ \\ ${ }^{1,3}$ Riga Technical University, Institute of Textile Materials Technologies and Design, ${ }^{2}$ Institute of Atomic Physics \\ and Spectroscopy of University of Latvia, ${ }^{4}$ Faculty of Biology of University of Latvia, ${ }^{5}$ Institute of Textile \\ Technology of RWTH Aachen, Germany
}

\begin{abstract}
Wearable biomonitoring systems and smart textiles for healthcare are gaining more importance and significance in the R\&D sphere due to their potentials in healthcare and sports. Such biomonitoring systems offer a number of advantages in comparison to the conventional equipment proving mobility of the wearer during a long-term monitoring of vital parameters. There are different options to set up the physiological monitoring using wireless and wearable technologies. One of the scenarios is addressing textiles as a carrier of electronics. Moreover, those differ by their functional applications, registered physiological parameters and technology solutions. Still, the most demanded biomonitoring smart systems focus on the examination of cardiovascular conditions due to the urgency of the problem in the public health. Furthermore, cardiovascular and haemodynamic parameters are initial physiologic criteria in sports physiology and in individual training. The common method for cardiovascular assessment is registration of heart electric potentials. Nevertheless, this research addresses photoplethmography (PPG) as an optional approach to acquire the information on cardiovascular and hemodynamic activity. The aim of the study is to develop a textile integrated optical sensor matrix for telemetric cardiovascular assessment. Two reflectance sensors with single and multiple photodiodes (PDs) based on a novel signal conversion were designed and adopted to textiles. Designed prototypes were evaluated for their technical parameters and biomonitoring performance in rest conditions. The acquired physiological data was analyzed by the custom developed software and compared to the reference data obtained by the medical ECG monitor. Overall, the textile adopted wearable systems with both types of PPG sensors have demonstrated high signal accuracy and potentials for wearable applications.
\end{abstract}

Keywords: wearable technologies, optical sensing, textileintegrated sensors, photoplethysmography, telemetric cardiovascular assessment, personalized healthcare.

\section{INTRODUCTION}

The innovations for healthcare sphere are highly demanded due to the changes in social and demographic, technologic and economic tendencies [1]. Telemetric systems for biometry based on smart textiles and wearable technologies have promising outlooks for medicine, personalized healthcare and sports due to the insurance of wears' mobility and enhancement of psychophysiological comfort during the biomonitoring procedure [2]. Smart clothing and wearable technologies embedded into textiles are in the focus of interest within healthcare oriented applied research projects for their potential advantages [3]. There is already a number of experimental developments and products available on the market that aim to enhance the quality of personalized healthcare. Those differ by their applications, implementation technologies and integration level functional element [4].

A great contribution was made to the research in wearable technologies for cardiovascular assessment and some of technologies have been transferred to the industry $[5,6]$. There is already a great variety of heart monitors based on textile electrodes and wireless technologies available on the market. Most of them are developed for the individual usage during physical activity to prevent inadequate high exercise intensities that might lead to over-training and can be harmful for health [7]. Such monitors usually register the difference of electrical potentials of myocardium and therefore provide limited information regarding hemodynamics. Optical diagnostics methods of the cardiovascular system ensure though non-invasive assessment of hemodynamic parameters, which indicate the functional state of blood vessels and cohered physiological processes. Some examples of optical sensing for physiological assessment by conventional equipment and wearable optical sensors are described in the literature [8-11].

This study focuses on photoplethysmography technique, which is relatively simple and low cost. In the frames of the research, a prototype of a wireless miniature device is developed for applications in textile integrated wearable systems for sports and healthcare. Moreover, the study suggests an innovative access to the signal acquisition technique. The developed device prototypes were embedded into textiles to create a wearable optical sensor matrix. Finally, the study investigates the PPG signal quality obtained from different sites of the body with a sensor incorporating multiple PDs and a single PD (Fig.1 (b, c)). The acquired data is used to evaluate further applications of the optical sensors in textile integrated wearable systems for sports and healthcare applications.

\section{MATERIALS AND METHODS}

\section{A. PPG measurement principles}

Photoplethysmography (PPG) is one of the promising noninvasive techniques for diagnostics and monitoring of the cardiovascular system [12]. The measuring technique is based on an optical detection of tissue blood pulsations. PPG signal consists of two components: slowly alternating DC component 


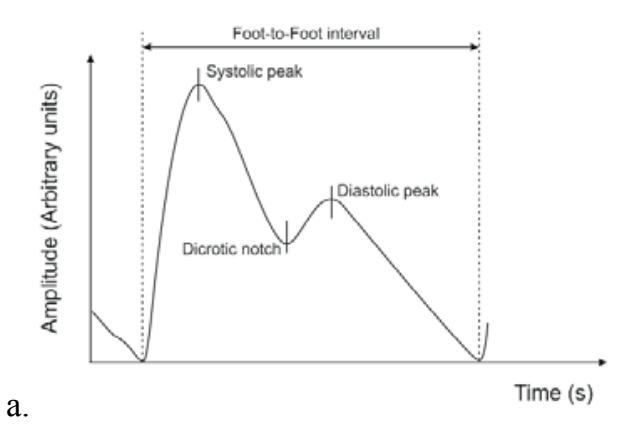

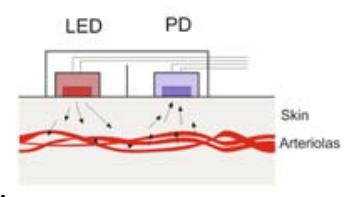

b.

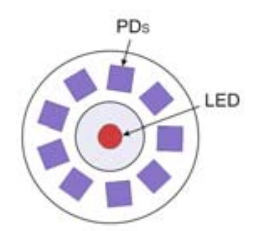

c.

Fig. 1. AC component of a typical PPG signal (a); convetional single PD (b) and developed multiple PD probe (c).

and pulsatile $\mathrm{AC}$ component, which takes only $0.5-2 \%$, of the DC offset [13]. The AC component reflects the vascular pulsations with each heart cycle, while the DC component reflects the total blood volume and its changes due to respiration, vasomotion, and neural activity [14] (Fig.1). A conventional PPG probe consists of an LED- photodiode configuration, where LEDs are light emitters and photodiodes (usually p-type, intrinsic, n-type diode (PIN)) are photodetectors (PD). In addition to the detector, good quality operational amplifiers and high resolution analog-to-digital converters are required. These components not only increase the system complexity and cost, but also the size and power dissipation, which is important in miniature battery-powered system.

There was an attempt to use such simplified techniques as the "pulse duration-based signal conversion technique", which is similar to the well-known single-slope A/D converter technique. The LED-LED technique was first proposed by Stojanovic et al. in 2007, and then implemented in other research projects $[15,16]$. Although being attractive for its simplicity, the LED-LED circuit provides PPG recording in a relatively small DC range. According to the studied literature, there were no studies reporting the use of "pulse-durationbased signal conversion" principle using a photodiode. Therefore, the study proposes a novel approach to a "pulseduration-based signal conversion" that incorporates single and multiple photodetectors and additional circuits.

\section{B. Device architecture and operation}

The electronic setup consists of three main wire-connected elements: a PPG sensor (either single PD or multiple PDs), a main electronic circuit, and a Li-ion battery integrated into the garment (Fig.2).

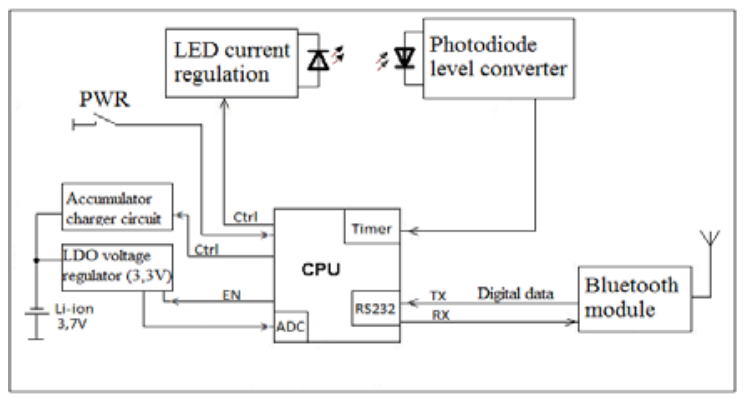

Fig. 2. Block diagram of the wireless PPG device: six blocks represent the principal modules and arrows indicate the interaction .
The prototype of the electronic circuit is built on the twolayer PCB. A single, low-noise, ultra-low dropout regulator (LP2985 by Texas Instruments) regulates a single lithium ion battery (nominal voltage of $3.7 \mathrm{~V}$ ) to produce a fixed output of 3,3 $\mathrm{V}$ for CPU and other LDO voltage regulator for the Bluetooth module. Charging of the battery is implemented by plugging in the device to a power source (charging current $100 \mathrm{~mA}$ ) using a micro-USB port charger IC LTC4054-4.2 by Linear Technology. The dimensions of the developed prototype are $21 \times 38 \times 5 \mathrm{~mm}$ (main board) suitable for integration into textiles.

The National Semiconductor LMX9838 Bluetooth Serial Port module is a fully integrated Bluetooth 2.0 baseband controller, $2.4 \mathrm{GHz}$ radio, crystal, antenna, LDO and discreet, which all are combined to form a complete small form factor (10 mm x $17 \mathrm{~mm} \times 2.0 \mathrm{~mm}$ ) Bluetooth node. A high-speed microcontroller NXP LPC2148 ARM7, which operates at $32 \mathrm{MHz}$ clock frequency, controls the PD sensor operation providing $1 \mathrm{~ms}$ time resolution of the registered PPG signal. The device operation state (operation mode) is indicated by two different color LEDs situated on top of the device cover, indicating the operation mode: power state, charging mode, and three discharge levels of the Li-ion battery. A reflection type PPG multiple and single photodiode sensor probes have been developed and adapted to PPG measurement from skin surface. The measurement probe is built on a small round PCB with diameter of $22 \mathrm{~mm}$, which contains electronic circuit see Fig. 3. The sensor consists of one infrared LED in the center of the pro be and nine photodiodes, which are located around the LED. A silicon photodiode OSRAM - BPW34-FA with daylight filter, $7 \mathrm{~mm}^{2}$ active surface area and peak spectral response wavelength $880 \mathrm{~nm}$ was selected.

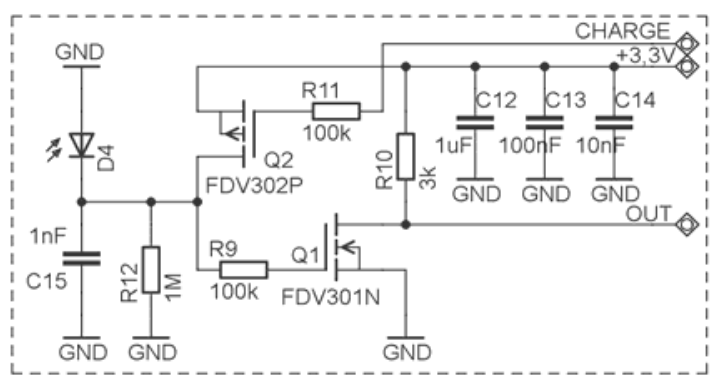

Fig. 3. Electronic circuit of the sensor. 
SMD infrared emitting diode model SIR91-21C/F7 with peak wavelength $875 \mathrm{~nm}, 20^{\circ}$ transmission angle and $1.9 \mathrm{~mm}$ diameter is used for building the probe. A screening barrier has been made around the LED in order to reduce the influence of the direct radiation on the photodiode. Such design of the probe expands the opportunities to acquire a more qualitative PPG signal from different sites of the body.

The signal conversion circuit of the sensor is rather simple. It consists of two Field Effect Transistors (FETs) and four resistors (Fig. 3). The ceramic capacitor with capacity of $1 \mathrm{nF}$ is connected in parallel to the photodiode. The photodiode capacity according to the manufacturer's specifications is $72 \mathrm{pF}$, which is small compared to the added capacity, which acts as a ballast.

The capacitor charging time $30 \mu \mathrm{s}$ is constant. It is the minimum required to charge the $1 \mathrm{nF}$ capacitor. Each charging cycle is followed by the discharge. Time of each discharge cycle is measured. When using the charge-discharge cycle measurement technique, the signal resolution decreases at higher light intensities on the photodiode D4 due to faster discharge of the capacitor $\mathrm{C} 15$, and vice versa.

\section{Software and operation}

The device operation requires an embedded firmware and Host PC installed software (DataScope, LU ASI).

The device firmware is a custom developed multitasking priority task scheduler executive. The required tasks and memory are all allocated as static for the reliability concerns. The software uses the power management for different operation modes to ensure an efficient energy usage and prolong the battery life. Moreover, the control of capacity charge and measuring of the discharge time are provided. To insure the connection between the device and PC host dedicated software, a binary serial command and data transfer protocol were developed (ASICMD). The software DataScope ensures solutions for capturing, monitoring, processing and storing the data. It sends and receives the data through a real

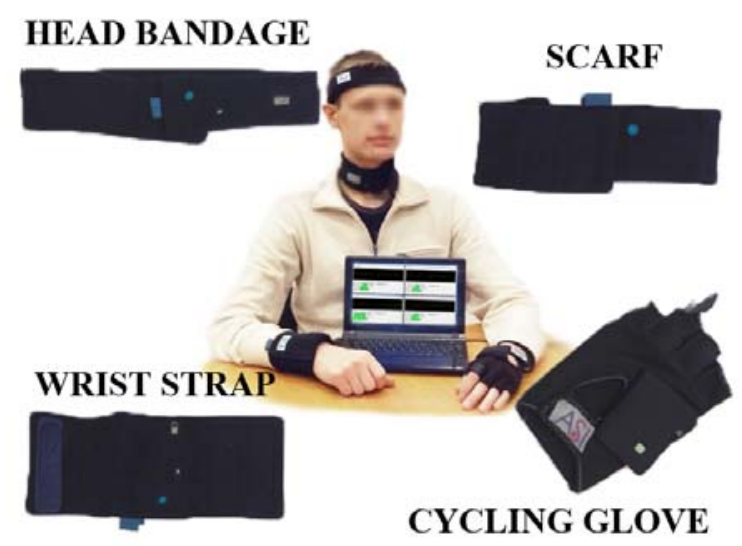

Fig. 4. Wearable single PD sensor matrix for sports applications or virtual serial COM port. The received data is stored in the memory. Further it is processed by the PPG analysis application and the algorithms for the heart pulse detection that are previously described in [16]. Then the captured signal and processing results are displayed on the screen in the realtime mode. In addition, the data are saved in the wave audio file format (WAVE) and can be processed in the compatible software.

\section{E. Prototype evaluation}

The evaluation procedure of the developed prototypes consisted of several steps. Initially, a bench test was carried out to obtain such device parameters as a dynamic range, signal noise ratio and linearity. Further the assessment of the biomonitoring performance of the prototypes was carried out according two scenarios. First a single PD sensor matrix embedded into the sports accessories was tested in rest condition (Fig.4). The next investigation was carried out to evaluate potentials of the sensor matrix in clothing applications and assess the quality of PPG signal acquired by a single and multiple PD probes from different body sites of the body (Fig.5). In both scenarios, the measurements were taken from young healthy volunteers in the same laboratory environment. All physiological data obtained with the developed prototype was compared to those registered by the commercial FDA approved medical device.

Bench test: Two $\mathrm{Hz}$ sine wave was produced by function generator TTi TG4001 (THURLBY THANDAR INSTRUMENTS), which was connected to the test LED 880 $\mathrm{nm}$ at $20 \mathrm{~mA}$. The test LED was situated perpendicularly $5 \mathrm{~cm}$ from the sensor photo detector (sensor built-in LED disabled) and placed in the dark testing chamber. During testing, the intensity and the offset of the sine wave modulated light were changed and acquired, and the signal was recorded by the custom developed dedicated software (DataScope).

In-vivo test for a single PD probe: The measurement series were estimated by the wearable prototypes with a single-PD probe.

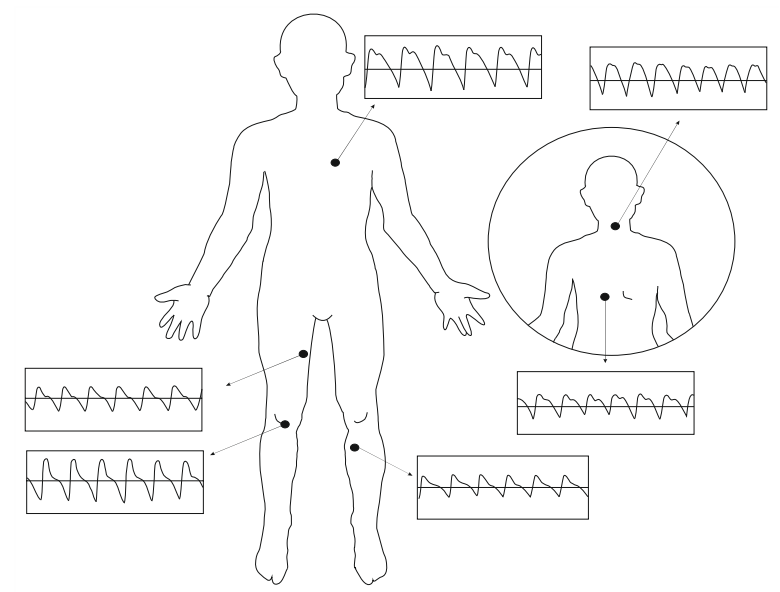

Fig. 5. Six body sites for PPG signal registration with the single and multiple PD sensors. The six windows display the typical PPG waveform of the particular recording site. The acquired waveform mostly depends on the pulse wave augmentation. 
The measurements were taken from six 24-29 years old females in the rest condition in the laboratory environment at room temperature $\left(25^{\circ} \mathrm{C}\right)$. The subjects gave an informed consent and all procedures were accepted by the Local Ethical committee of University of Latvia. The ECG signal (TLC5000 12 Channel Holter ECG Monitor System, Contec Medical Systems) as the reference and the PPG as a test signal were recorded simultaneously.

The sports accessories were developed considering the particularities of physiological measurements and the sensor probe was applied to the relevant signal acquisition area (Table 1). Each measurement record was taken three times for 120 seconds. Then the obtained physiological data was processed and statistically described.

TABLE I.

RELEVANCE OF THE CLOTHING TYPE AND PPG SIGNAL REGISTRATION

\begin{tabular}{|l|l|}
\hline Prototype & Signal acquisition area \\
\hline Head bandage & Temporal artery \\
\hline Cycling glove & The $1^{\text {st }}$ phalange of the forefinger \\
\hline Wrist strap & Radial artery \\
\hline Scarf & External carotid artery \\
\hline
\end{tabular}

In-vivo test for a single and multiple PD probe: Several recording sets with a single-PD sensor probe and multiple-PD PPG sensor probe were performed. The measurement conditions and the experimental set-up were the same as in the first evaluation test. The experimental protocol consisted of two parts. The first measurement set was taken by a single PD sensor from six different sites of the body (Fig.5). The second set was taken by the multiple - PD sensor from the relevant body sites of the same person. Each of the 120-second measurement was repeated three or four times in order to reveal the converged correlation coefficient between the acquired data. The measurements were statistically processed and correlation analyses and relevant tests were applied for the data comparison and evaluation. The summary results were depicted as the mean \pm standard deviation.

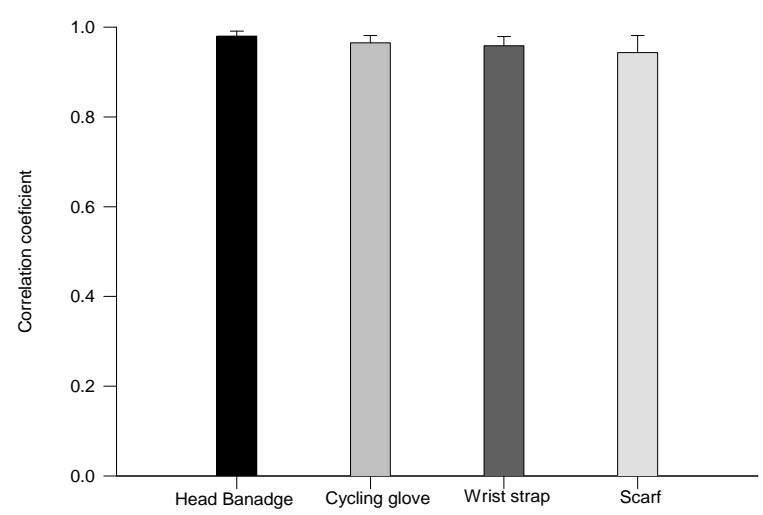

Fig. 7. Evaluation of the wearable single PD sensor matrix for sports applications

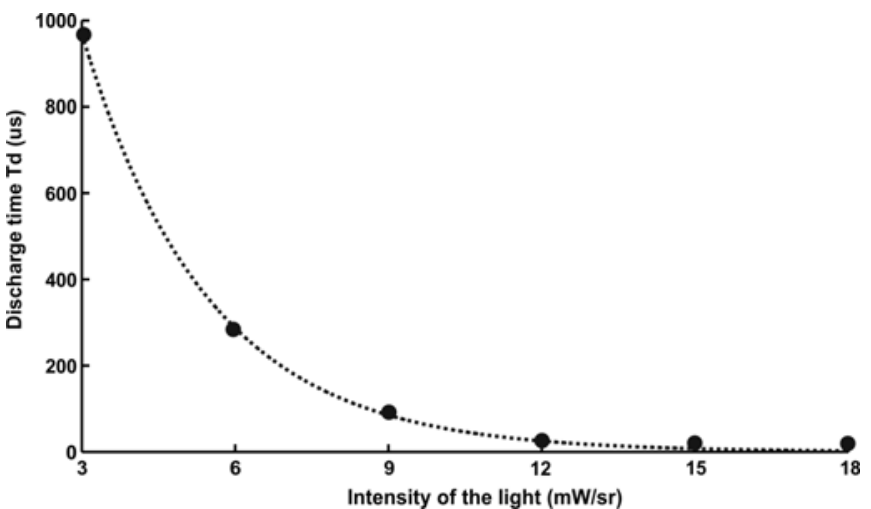

Fig.6. Representative example of PD discharge time curve. Black circles represent discharge time (PPG amplitude) measured at six light intensities. Dotted curve was reconstructed by exponential fitting.

\section{RESULTS}

Bench test: The technical parameters obtained by the single and multiple PD showed no significant difference between the sensors when the artificial signal - sine wave modulated light source was applied. The average value was SNR $=86.56 \pm 3.00 \mathrm{~dB}$ and dynamic range $89.84 \mathrm{~dB}$. The linearity of the device performance along the dynamic range is depicted in Figure 6. The average peak to peak noise is $-71.78 \pm 1.50 \mathrm{~dB}$.

In-vivo test for a single PD probe: For the data analysis, 72 measurement records were selected to describe the operation efficiency of the developed prototypes. As the pulse duration is identified with the length of the foot-to-foot interval for PPG signal and R-R interval for ECG signal, the values (ms) were extracted from the obtained data and compared. All prototypes have demonstrated excellent performance and relevant measurement accuracy for sports applications (Fig.7).

The data selection was quite homogenous and has passed the normality Shapiro-Wilk test. The highest correlation of the measurements was observed in the results obtained by the sensor embedded into the head bandage $(r=0.99 \pm 0.03$; $\mathrm{p}<0.001)$ and the cycling glove $(\mathrm{r}=0.97 \pm 0.02 ; \mathrm{p}<0.001)$. Less accurate signals were obtained with the wrist strap $(r=0.96 \pm 0.02 ; \mathrm{p}<0.001)$ and the $\operatorname{scarf}(\mathrm{r}=0.94 \pm 0.04 ; \mathrm{p}<0.001)$.

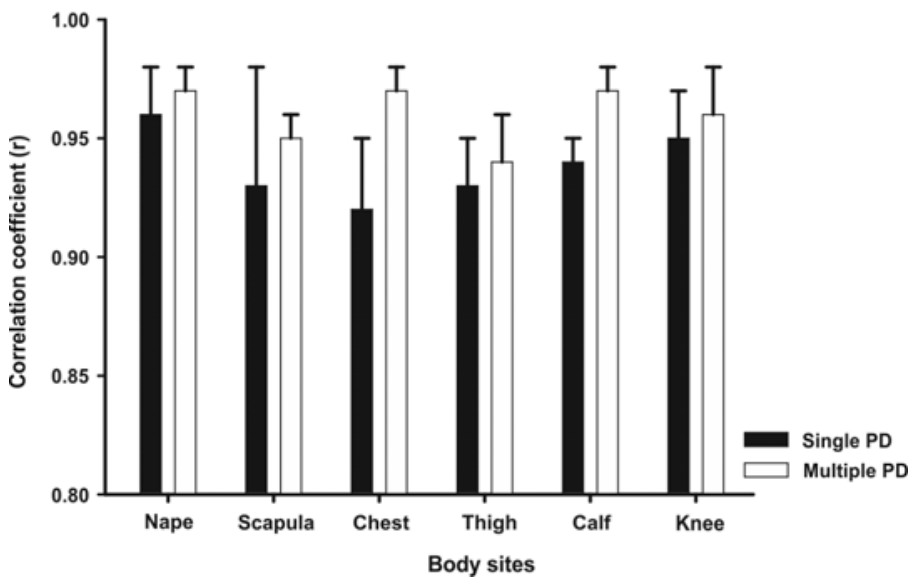

Fig. 8. Correlation coefficients (mean and standard deviation) for the heart rate values derived from the simultaneously registered PPG and ECG signal. The data is acquired from six females at six different body sites 
In-vivo test for a single and multiple PD probe: In total, 216 measurements were acquired by the single-PD PPG device and the multiple-PD PPG sensor. In general, the heart rate (HR) values simultaneously obtained from the PPG signal and ECG showed high correlation $(r=0.94 \pm 0.15 ; \mathrm{p}<0.001)$. However, the calculated values differ when the measurement results estimated by the multiple-PD and single-PD sensor probes were compared (multiple PD $\mathrm{r}=0.97 \pm 0.01$ versus single PD $r=0.93 \pm 0.02$ ). Moreover, it was observed that the measurement quality and signal form vary significantly in the different body sites (Fig.8).

\section{DISCUSSION}

In this study, a prototype of a PPG sensor matrix has been developed and evaluated for its potentials in textile and clothing applications for sports and healthcare.

The first significant achievement of the research is the development of a wearable miniature PPG device for telemetric assessment of cardiovascular and hemodynamic parameters. The operation of the developed device is based on a novel approach to the pulse duration measurement. The technique of a signal conversion incorporates a photodiode and accessory circuit. Thus, this method of the signal acquisition ensures operation of the device without application of analog operation amplifiers and filters. Such an approach significantly enhances the quality of the registered signal and simplifies the technical solutions reducing the dimensions of the device and making it more lightweight. Moreover, the power management in the device has been also improved. The current solution provides a longer battery-life and no power loss in the power-off mode.

Then two types of a PPG optical sensor were designed and developed: a conventional type single-PD and a multiple-PD probe. The sensor probes were adapted to textiles and the device was integrated into clothing to create an optical matrix for cardiovascular and hemodynamic assessment. Initially the single-PD probe was embedded into several sports accessories. The construction of the textile prototypes was developed according to the requirements for the physiological signal acquisition and to ensure an easy and accurate on-body attachment. Still, to obtain a qualitative signal from other body site a multiple-PD probe was designed and integrated into textiles. The device was evaluated through bench testing for its technical parameters and wearable prototypes were tested for their biomonitoring performance.

The results of the bench testing of the developed wearable device showed good values of SNR and dynamic range. The signal was though fairly linear and slightly exponential along the whole DC range. The non-linearity was possibly caused by the PD's internal series resistance, which makes the capacitor discharge exponential. Since the AC component is small (0.2$1 \%$ ) in comparison to the DC component, PPG AC signal distortions can be neglected. Despite of the exponential nature, no visible waveform distortions were observed in the real invivo recorded PPG signal. This phenomenon can be caused by the nature of the PPG AC component, which swings slowly.
Thus, the amplitude of the whole pulse period is equally affected and the PPG signal amplitude is normalized along the beat period. Similarly, the exponential relationship between the input and output signal was observed in the LED-LED based circuit, which indirectly indicates the inherited nonlinearity of all the pulse-duration-based signal conversion circuits [15]. The hypothetic solutions of the problem are the compensation function, which can increase the number of elements and, hereby, resemble the complexity of latest the hiend ADC chip.

The initial expertise of the single-PD sensor matrix embedded into the sports accessories evinced the efficiency of the biomonitoring system in the rest conditions. The prototypes of the head bandage and the cycling glove showed the highest measurement accuracy and stability. Moreover, those were the more comfortable in use and easy to adjust the sensor probe to the examined area.

Further potentials for the wearable sensor matrix were explored in the next experimental procedure using a single-PD and multiple-PD sensors. Measurements from the body sites examined earlier with the single-PD probe were omitted in the second test due to less expedience of the large area sensor use in the described applications.

The second in-vivo test revealed a high correlation of HR values acquired with the developed prototypes and the reference data. When comparing the HR values obtained from the different body sites, the highest similarity was achieved when registering the PPG signals from the nape, chest, and calf. The efficiency of the developed sensors has been indirectly verified by comparing the HR values measured by the multiple-PD sensor and single-PD sensor. The multiplePD sensor appeared to be more accurate in these applications, showing higher correlations with the reference data in comparison to the single-PD sensor. Hence, the multiple-PD sensor was more sensitive to body motions and sensor-totissue contact force. In these tests, the efficiency of the developed sensors has been evaluated in the real PPG measurement conditions due to the complexity of the computation of the HR values. The main advantage of the multiple-PD probe is large sensor area of the signal acquisition from the sites of the body with weak blood pulsations. Moreover, the developed design of the sensor probe ensures easy and efficient integration of the sensor into textiles.

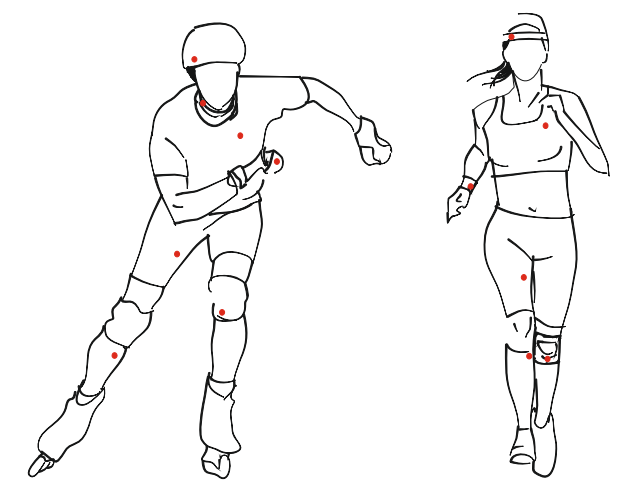

Fig. 9. Potential applications of the wearable sensor matrix in sports clothing 


\section{V.CONCLUSIONS}

The developed methodology of PPG signal acquisition has several advantages in comparison to conventional $\mathrm{PPG}$ recording methods, i.e. low noise and low power consumption. Due to its low weight, miniature dimensions and acquisition of PPG signals in the reflectance mode, the developed prototypes have promising applications in clinical assessment and wearable electronics for sports and healthcare. The developed wearables have a variety of applications in such sports accessories as gloves, knee support bandages or protectors, head bandage, helmet and others (Fig.9). They have also potentials for use in compression textiles, e.g. socks, to examine relevant physiological parameters and make an asset in evaluation of the compression therapy efficiency [16]. Moreover, the developed prototypes have potentials in use for hemodymanic parameters evaluation that till now is ensured by such conventional stationary equipment as finameter.

\section{REFERENCES}

1. Van Langenhove, L. Smart Textiles for Medicine and Healthcare Applications. Materials, Cambridge: Woodhead Publishing, 2007. http://dx.doi.org/10.1533/9781845692933

2. Chan, M. et al. Smart Wearable Systems: Current Status and Future Challenges. Artificial Intelligence in Medicine, 2012, 56, pp.137-156. http://dx.doi.org/10.1016/j.artmed.2012.09.003

3. Van den Kirboom, E., Byluppala, M.R. Systex-Coordination Action for Enhancing the Breakthrough of Intelligent Textile Systems (E-textiles and Wearable Microsystems), Systex FP7-ICT-207.3.6, University of Ghent, 2011.

4. Cherenack, K., van Pieterson, L. Smart Textiles: Challenges and Opportunities. Journal of Applied Physics, 2012, 112, pp. 1-15. http://dx.doi.org/10.1063/1.4742728

5. Heuberger, M., Correvon, M. Smart Textiles- from Base Technology to Human Vital Sign Monitoring [Online]. CSEM/EMPA, Duebendorf, 2011-[Assessed 10.08.2013]. Available: Manfred.Heuberger@empa.ch.

6. Hanus, S. et al. Smart Textiles for Medical Applications [Online]. Smart Textiles in Thueringen/Germany, Textile Research Institute ThuringiaVogtland e.V. 2012- [Accessed 28.09.2013]. Available: d.zschenderlein@titv-greiz.de

7. Budinger Thomas F., Biomonitoring with Wireless Communication. Palo Alto, USA: Annual Reviews of Biomedical Engineering, 2003.

8. Krebber, K. et al. Optical fibre sensors embedded into technical textile for healthcare (OFSETH). $16^{\text {th }}$ International Conference on Plastic Optical Fibre, Italy, Torino, 2007 pp.227-233

9. Witt, J. et al. Fiber optic heart rate sensor for integration into personal protective equipment, International Workshop BioPhotonics, Italy, Parma, 2011, pp.1-3

10. Reiter, H. The Development of E-Health in the Field of Cardiovascular Medicine. The Role of Smart Textiles [Online]. EHRA Summit, 2010[Accessed 17,.9.2013]- Avialable: herald.reiter@philips.com

11. Pandian, P.S. et al. Smart Vest: Wearable multi - parameter remote physiological monitoring system. Medical Engineering \& Physics, 2008, 30,pp. 466-477. http://dx.doi.org/10.1016/j.medengphy.2007.05.014

12. Allen, J., Photoplethysmography and its application in clinica physiological measurement. Physiological Measurement, 2007, Vol. 28., pp.1-39. http://dx.doi.org/10.1088/0967-3334/28/3/R01

13. Lin, C.-H. et al.Chaos Synchronization Detector Combining Radial Basis Network for Estimation of Lower Limb Peripheral Vascular Occlusive Disease. Medical Biometrics: Second International Conference, Hong-Kong, 2010.

14. Stojanovic, R., Karadaglic, D. A LED-LED-based photoplethysmography sensor, Physiological Measurement. 2007, 28, p. 19-27. http://dx.doi.org/10.1088/0967-3334/28/6/N01

15. Ragib, A.M. Low Cost Heart Rate Monitor Using Led-Led Sensor, AlKhwarizmi Engineering Journal., 2009, 5, N 3, pp. 23 - 27.

16. Marshall, M., Wienert, V. Effects of Medical Compression Stockings on Venous Haemodynamics Determined by Ppotoplethismograpy. Phlebologie, 2013, 1, pp.19-23.

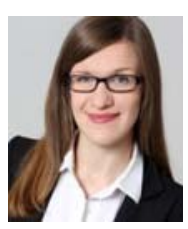

Viktorija Mečñika, Ms.sc. is a Doctoral student of the Institute of Textile Technology and Design of Riga Technical University after receiving a Master's degree in Clothing Technology in 2010.

During the Engineer and Master studies she gained work experience in textiles ,apparel retail and fashion management with the focus on high-street and luxury brands.

Since 2010 she has been employed as a Scientific Assistant at Riga Technical University and University of Latvia ("Biophotonics Research Group"). Since 2012 till present she has been involved in research activities at the Institute of Textile Technology of RWTH Aachen, Germany. The research sphere covers the field of innovative textiles and clothing for a variety of technical and functional applications. Professional interests include anthropology study for clothing design and textile commodity sciences.

Address: Riga Technical University, Institute of Textile Materials Technologies and Design, Azenes Str. 18, Riga, LV-1048, Latvia E-mail: viktorija.mecnika@rtu.lv

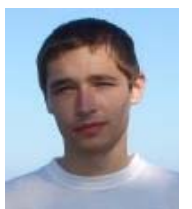

Edgars Kviesis-Ķipge, Dr. phys. got Doctoral Degree in Physics in 2013 at the University of Latvia after graduating from Master's Degree studies in 2008.

Since 2005 has been employed as an Electronics Engineer and during 2010-2012 held the position of an Administrator of the sub-activity in the "Biophotonic Research Group" project.

At present he is a Researcher at the Institute of Atomic Physics and Spectroscopy of University of Latvia and carries out development and testing of experimental equipment for physiological assessment by optical methods. The main fields of research are medicine physics, electronics, remote data transmission, development and manufacturing of electronic devices.

Address: Address: University of Latvia, Raina Blvd 19, Riga, LV-1586, Latvia

E-mail: janispi@latnet.lv

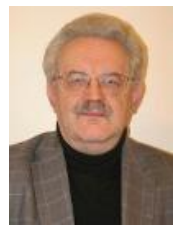

Ivars Krieviňš, Dr.sc.ing. after professional studies at Leningrad Technological Institute for Textile and "Light" Industry (1969 - 1974) became a designer and technologist for sewn products engineering; After doctoral studies at Moscow Technological Institute of Light Industry (1980 - 1984) got the degree of Candidate of Technical Sciences in the field of «Technology of Sewn Products (05.19.04)», later got the scientific degree of Doctor of Engineering

Sciences (Dr.sc.ing.) by the Resolution 1993-06-16 of the RTU Promotion Council P-11 in the field of "Technology of "Light" and Textile Industry Products" which was renamed "Textile and Clothing Engineering". Currently Associate Professor at the Riga Technical University (RTU), Institute of Textile Materials Technologies and Design, Department of Clothing and Textile Technologies, Āzenes 14, Riga, Latvia. Previously jobs for the Department of "Light" Industry Machinery and Technology at Riga Polytechnical Institute: (later Institute of Textile and Clothing Technology at RTU).

Chairman of the Textile Terminology Commission at the Latvian Academy of Sciences; (1992 to present); Chairman of the Technical Committee for National Standardization Body LVS/STK/41 "Textiles and Leather" (1997 2002); Textile Expert of the Ministry of Economics for the EU Textile Labelling Committee (2000 to present); Membership at The International Textile Institute (1993 - 2000); Member of the RTU Promotion Council RTU-P-11 (1998-2005); Membership in RTU Engineering Faculty Council $(1992-2002$

Address: Riga Technical University, Institute of Textile Materials Technologies and Design, Azenes Str. 18, Riga, LV-1048, Latvia

E-mail: ivars.krievins@rtu.lv 


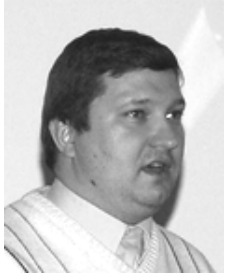

Zbigṇevs Marcikevičs, Dr.biol. got a Doctoral Degree in Biology in 2013, . Master's Degree in Biology - in 2002.

During Doctoral studies had professional trainings at Umea University (Sweden) and Bremen University (Germany). Since 2006 has been working as a Scientific Assistant in the Department of Human and Animal Physiology at the Faculty of Biology of the University of Latvia.

Since 2010 till 2012 was a Leading Researcher of a physiology research group in ESF research project "Biophotonic Research Group". At present is employed as a Researcher at the Faculty of Biology of the University of Latvia. Member of the Latvian Society of Physiology.

Address: University of Latvia, Kronvalda Blvd. 4, Riga, LV-1010, Latvia

E-mail: zbignevs.marcinkevics@lu.lv

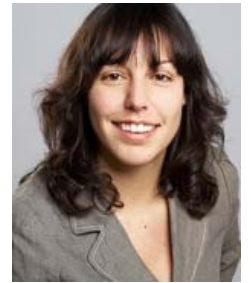

Anne Schwarz, Dr.sc.ing. is a scientific researcher at the Institut für Textiltechnik (ITA). Dr. Schwarz is a textile engineer, specializing in smart textiles. She leads the section Smart Textiles at the ITA. She possesses European research experience due to her work at Ghent University in Belgium over six years. Her areas of specialization include smart protective and medical clothing and coating of textile materials with conductive and interactive layers.

Address: Institut fur Textiltechnik der RWTH Aachen, Otto-Blumenthal Str.1. 4, 52074 Aachen, Germany

E-mail: anne.schwarz@ita.rwth-aachen.de

\section{Viktorija Mečņika, Edgars Kviesis-Ķipğe, Ivars Krieviṇš, Zbignevs Marcinkevičs, Anne Schwarz. Valkājamā PPG sensoru matrica kardiovaskulāro parametru novērtēšanai}

Valkājamās biomonitoringa sistēmas un viedās tekstilijas veselības aprūpei iegūt arvien lielāku nozīmi pētniecības jomā, pateicoties to potenciālo pielietojumu dažāāībai veselības aprūpes un sporta sfērā. Šādām biomonitoringa sistēmām ir vairākas priekšrocības salīdzinājumā ar konvencionālo aprīkojumu. Tomēr svarīgākais šādu sistēmu raksturojums ir valkātāja nodrošināšana ar kustības brīvību ilglaicīgās fizioloğiskās uzraudzības laikā. Pastāv vairākas iespējas nodrošināt fiziologisko monitoringu, balstoties uz bezvadu un valkājamām tehnolog̣ijām. Viens no šādu izstrādājumu īstenošanas veidiem ir tekstiliju izmantošana kā elektronikas sistēmas nesējs. Turklāt šādas sistēmas atškiras pēc sava funkcionālā pielietojuma un reǵistrējamiem parametriem. Tomēr vislielāko interesi pētniecības jomā un industrijā izraisa viedās sistēmas sirdsdarbības uzraudzībai. Primāri tas ir saistīts gan ar kardiovaskulāro slimību problēmas aktualitāti sabiedrības veselībā. Turklāt, sirdsdarbības un hemodinamikas parametri ir vieni no galvenajiem fiziologiskā stāvokḷa rādīiājiem sporta nodarbību laikā, kā arī citās profesionālās aktivitātēs. Visizplatītākā metode kardiovaskulāro parametru izvērtěšanai ir sirds elektriskā potenciāla noteikšana. Tomēr šajā pētījumā fotopletismogrāfija (PPG) ir izskatīta kā alternatīva metode fiziolog̣iskās informācijas iegūšanai par kardiovaskulāro un hemodinamisko parametru stāvokli. Pētijijuma galvenais mērkis ir izstrādāt tekstila iestrādāto optisko sensoru matricu telemetriskajam biomonitoringam. Sākotnēji tika izstrādāti un integrēti tekstilijās divi PPG sensori ar vienu un vairākām fotodiodēm (PDs), kas darbojas pēc remisijas principa un balstās uz jaunradīto signāla pārvēršanas metodi. Tika izvērtēti izstrāāāto prototipu tehniskie parametri un to funkcionalitāte ar fiziolog̣iskiem mērījumiem miera stāvoklī. Iegūtie fiziolog̣iskie dati tika apstrādāti jaunradītajā programmatūras vidē un salīdzināti ar references datiem, iegūtiem ar medicīnisko EKG reǵistrēšanas aprīkojumu. Kopumā tekstilā iestrādātās valkājamās sistēmas ar abu konfigurāciju PPG sensoriem parādīja signāla augsto precizitāti un izredzes valkājamam pielietojumam.

Виктория Мечника, Эдгарс Квиесис-Кипге, Иварс Криевиныш, Збигневс Марцинкевич, Анне Шварц. Матрица ФПГ сенсоров для наблюдения показателей сердечно-сосудистой системы интегрированная в предметы одежды.

Системы биомониторинга, интегрированные в предметы одежды, и высокотехнологичные текстильные изделия для наблюдением и уходом за здоровьем приобретают все большую значимость в сфере научно-исследовательских разработок благодаря широким возможностям их применения в области здравоохранения и спортивной медицины. Такие системы биомониторинга обладают рядом преимуществ по сравнению с конвенциональным оборудованием, обеспечивая носителя системы свободой передвижения во время длительного медицинского наблюдения и не причиняя значительного дискомфорта. Существует несколько способов технической реализации подобных систем с применением беспроводных технологий. Один из широко распространенных вариантов проектировки подобных изделий - это использование текстиля как носителя электронных компонентов. Более того, такие системы различаются по назначениям в использовании и регистрируемым физиологическим показателям. Однако наибольший интерес как в научно-исследовательской среде, так и в индустрии, вызывают высокотехнологичные текстильные изделия для наблюдения и оценки деятельности сердено-сосудистой системы. В первую очередь это связано с ростом сердечных и сосудистых заболиваний и повышением количства пациентов, находящихся в группе риска. К тому же, сердечно-сосудистые и гемодинамические параметры являются важнейшыми физиологическими показателями во время занятиий спортом и работы специалистов ряда профессий (работники спасательных служб, военнослужащие и т.д.). Наиболее распространенный способ определения показателей работы сердца - это регистрация электрических потенциалов, образующихся в результате сокращения сердечных мышц. В данном исследовании фотоплетизмография рассматривается, как альтернативный метод получения физиологической информации о сердечно-сосудистых и гемодинамических показателях. Главная цель исследования заключается в разработке матрицы оптических сенсоров на основе текстильных изделий для телеметрического наблюдения. Изначально были разработаны два ФПГ датчика с одним и несколькими фотодиодами (ФД), которые действуют по принципу ремиссии и основываются на инновативном методе регистрации сигнала. Далее была произведена оцека технических параметров разработанных прототипов и их пригодности в использовании с помощью проведения ряда физиологических измерений в состоянии покоя. Полученные физиологические данные были обработаны при помощи специально разработанной программатуры; далее был произведен их анализ и оценка в сравнении с показателями, зарегистрированными медицинским ЭКГ монитором. Результаты экперимента показали высокую точность измерений, произведенных ФПГ сенсорами обоих конфигураций, и возможность дальнейшего использования разработанной системы в спортивной и биомедицинской одежде. 